\title{
PRISONERS AND BOARDS OF VISITORS' HEARINGS; A RIGHT TO LEGAL REPRESENTATION AFTER ALL?
}

Since the English Court of Appeal announced the demise of the courts" "hands off" policy regarding the judicial review of the actions of prison authorities in the St Germain ${ }^{1}$ case in 1978 the Divisional Court has been kept busy by cases emanating from Britain's prisons. Much of this litigation has concerned exploring the contours of the Boards of Visitors' duty to observe the rules of natural justice when hearing disciplinary charges against a prisoner which was enunciated in $S t$ Germain. ${ }^{2}$ One requirement which was always likely to be suggested as necessary to comply with that duty was a prisoner's right to legal representation, for although the Court of Appeal had decided in Fraser v $M u d g e^{3}$ that a prisoner had no right to representation in a Board of Visitors' hearing that was a pre St Germain decision, made at a time when, as Lord Denning MR put it, the courts would not entertain actions from "disgruntled prisoners". ${ }^{4}$

The right to legal representation has duly been considered by the English Divisional Court, ${ }^{5}$ the Northern Ireland Court of Appeal, ${ }^{6}$ the European Court of Human Rights, ${ }^{7}$ and the government-appointed Prior Committee on Prison Discipline. ${ }^{8}$ Each has concluded that there exists no absolute right to legal representation but that in certain circumstances the Board of Visitors should grant a prisoner's request for such representation. This might seem to have put an end to the matter. However, such has been the importance placed by prisoners and their lawyers on this right, and so consistent and extensive their pursuing of it, that a final resolution of the issue seems unlikely until the ultimate tribunals of the House of Lords and Parliament have considered the question. $^{9}$

It is the contention of this article that, should these tribunals come to consider the issue of a prisoner's right to legal representation, there are strong reasons for granting it. I hope to show that previous arbiters on the question have failed to consider adequately the issues involved and that the obstacles they have placed in the way of recognising such a right are

$R$ v Hull Prison Board of Visitors, ex parte St Germain [1979] QB 425.

$R$ v Hull Prison Board of Visitors, ex parte St Germain (No 2) [1979] 3 All ER 545. [1975] 1 WLR 1132.

See Becker v Home Office [1972] 2 QB 407.

5 See $R$ v Secretary of State for the Home Department, ex parte Tarrant [1984] 1 All ER 799.

6 See $R$ v Board of Visitors HM Prison Maze, ex parte Hone, ex parte McCartan noted (1986) 8 BNIL 80.

7 See Campbell and Fell v United Kingdom (1985) 7 EHRR 165.

8 See Report of the Committee on Prison Discipline (Cmnd 9641, 1985).

9 The European Court of Human Rights is, of course, a final tribunal within the Convention system. However, it is arguable that the question of whether a prisoner has a right to legal representation in all cases before Boards of Visitors has never been precisely framed for it. 
not insurmountable. The article includes arguments of both "law" and "policy" as I believe that in this area courts have concerned themselves with questions of policy, while politicians are likely to debate the issue in terms of rights. The article is divided into five sections. The first section considers the domestic law rejection of a right to representation and advances reasons for finding this unsatisfactory. The second looks at the jurisprudence of the European Commission and Court of Human Rights on the question. The third examines the Tarrant decision and the application of Webster J's criteria in subsequent judicial review decisions. It will be argued that the courts have undervalued legal representation, seeing it as something necessary to ensure natural justice where disciplinary hearings depart from the "normal" rather than as an essential element of those "normal" hearings themselves. The fourth section examines the Prior Committee's reasons for the rejection of a right to representation and suggests that these are an unsatisfactory basis for legislation, especially in the light of governmental rejection of other main tenets of the Prior approach. Finally, a conclusion draws these four sections together and offers some tentative consideration of the desirability of extending the legalisation of prison life.

\section{UNITED KINGDOM LAW AND THE RIGHT TO REPRESENTATION}

Perhaps the first obstacle in the way of recognising any right to legal representation is that courts have constantly affirmed, most notably in Tarrant itself, that tribunals, including Boards of Visitors, have the right to determine their own procedure. That this right has been successfully asserted to defeat claims for legal representation in Magistrates' Courts, ${ }^{10}$ often invoked by prisoners' rights advocates as the most appropriate analogy to Board of Visitors hearings, appears to cast a particularly dark shadow over the prisoners' case. However, on closer examination this principle is shown to have limitations. For one thing most of the cases cited to support it turn out to be concerned with rights of audience, normally the right of the prosecution, ${ }^{11}$ or of third parties, ${ }^{12}$ to be represented by lawyers, rather than with ensuring natural justice for the defendant. For another, when natural justice claims have been raised, the courts have produced decisions which, while formally preserving the discretion, have in fact sharply circumscribed it. In St Germain, for example, the Divisional Court recognised that the Board had a discretion whether or not to allow the prisoner to call witnesses or cross-examine, yet went on to hold that failure to exercise this would in most circumstances be unfair. Indeed one court has subsequently asserted that failure

10 See, eg, Collier v Hicks 2 B \& D 663, 109 ER 1290 (1831); Cox v Coleridge 1 B \& C 37, 107 ER 15 (1822); May v Beasley [1910] 2 KB 722; O'Toole v Scott [1965] AC 939; $R$ v Milton Keynes $\mathcal{f}$ ustices, ex parte Russell [1979] I WLR 1062; $R$ v Newbury fustices, ex parte Pont (1984) 78 Cr App R 255.

11 See Collier v Hicks, O'Toole $\mathbf{v}$ Scott, May v Beasley cited previous note.

12 See $R$ v Milton Keynes fustices, ex parte Russell, supra. 
to allow a prisoner to call a witness is "prima facie unfair". ${ }^{13}$ The Tarrant court, while bound by authority to state that no right to representation existed, nevertheless suggested that failure to exercise the discretion in favour of prisoners charged with mutiny would be unfair.

This approach to the issue of the Boards' discretion suggests that discretion is circumscribed by the requirement of natural justice, and that where there is a conflict, the latter prevails. While natural justice requires only a procedural minimum, it will be argued that this minimum must be evaluated relative to the nature of the proceedings and interests at stake. So far the courts have recognised that a right to call witnesses and conduct cross-examination is part of that minimum, and that legal representation forms part of it in specific circumstances. The issue to be debated here is whether anything prevents them from holding it is part of the minimum in all cases. If no obstacle in principle or precedent can be found, the simple assertion of the tribunal's right to control its own procedure should hardly be enough to dispose of the issue.

Before moving on to the issue of whether natural justice requires a right to legal representation in any circumstances, and more particularly in the context of Boards of Visitors' disciplinary hearings, it is worth considering the other major ground for asserting such a right, that founded on agency principles.

This argument is usually derived from the Court of Appeal decision in $R$ v St Mary Abbotts Kensington Assessment Committe ${ }^{14}$ wherein the Court held that any one who had a right to appear before a tribunal had a common law right to appear by an agent, in that case a surveyor. Alder ${ }^{15}$ argues that the agent could be a lawyer and that the right can be excluded only by contract or by statute or where the proposed representative is "manifestly improper". This argument was raised neither in Fraser v Mudge nor in Tarrant but was the subject of quite extensive discussion in the recent Northern Ireland Court of Appeal decision of In re Hone and McCartan's applications. ${ }^{16}$

There two prisoners in the Maze were charged with assault and, following a Board hearing, Hone, a life sentence prisoner ineligible for remission, lost 60 days privileges and was ordered to spend 30 days in cellular confinement. McCartan, serving a 24 year sentence, received an effective penalty of 100 days loss of remission and 20 days cellular confinement on two assault charges. Both applied for and were refused legal representation. The Board's decisions to refuse representation was upheld by Gibson LJ. The prisoners appealed seeking the quashing of the decision on the grounds of either the Board's failure to recognise their

13 See $R$ v Nottingham Prison Board of Visitors, ex parte Mosley, The Times, 23 January 1981.

14 [1891] l QB 378.

15 Alder, "Representation before Tribunals" (1972) PL 278.

16 See supra $\mathrm{n} 6$. 
right to representation (based on agency, natural justice or the European Convention) or, alternatively, of an unreasonable exercise of its discretion to grant representation.

Lord Lowry LCJ concluded that the scope of any such common law right did not encompass the right to be represented by a lawyer in Boards of Visitors' hearings. He derived this conclusion largely from the rejection of any unrestricted right by Lyell J in Pett v Greyhound Racing Association $\mathrm{No} 2,{ }^{17}$ a view subsequently endorsed by Lord Denning MR in Enderby Town Football Club v Football Association. ${ }^{18}$ Further support for Lord Lowry's views came from the decision of Gibson J (as he then was) in In re Mackey's application. ${ }^{19}$ There the Court held that where an internee had a right to appear before an advisory committee to question his continuing internment, a lawyer could appear as his agent but not as his legal representative. Gibson J stated that "the relationship of a client to his solicitor and counsel is not that of principal and agent".

These decisions have not gone without criticism. In respect of the first two, Alder argues that they erroneously suggest that the right is dependent on the exercise of the tribunal's discretion. De Smith ${ }^{20}$ commenting on In re Mackey's application noted that the distinction between lawyer as common law agent and as legal representative was seen as immaterial by the High Court of Australia in $R$ v [Parole] Board, ex parte Kay. ${ }^{21}$ Indeed, if what is at stake here is that a lawyer is bringing his own skills to the matter rather than simply acting as his client's substitute, then it would seem that even the St Mary Abbotts case permits this, as in that case the surveyor was chosen particularly for his specialist knowledge of assessments. ${ }^{22}$

Overall Lord Lowry LCJ's conclusion that precedent did not clearly establish such a right and that to recognise it would lead the court into conflict with authoritative pronouncements directed to "natural justice, public policy, administrative convenience and good sense"23 - that it would, for example, allow legal representation to be claimed at governors' hearings-contrasts with his fearless approach in In re McKiernan's application. ${ }^{24}$ In that decision he took the view that where no authoritative precedent indicated otherwise principle was to be followed regardless of the implications for administrative convenience or public policy. It will be argued below that such a principle favouring legal representation does exist and no precedent clearly requires its rejection. Ironically were the courts to decide that a right to legal representation in

17 [1970] 1 QB 46.

18 [1971] $1 \mathrm{Ch} 591$.

19 (1971) NIJB (Nov/Dec).

20 "Internment and Natural Justice" (1972) 23 NILQ 331.

21 (1916) 22 CLR 183.

22 Indeed ironically in that case the committee had no objections to the householder's solicitor acting as his agent before them.

23 All quotations are from the transcript of the judgment.

24 (1986) 6 NIJB. 
Board hearings should be granted but to remain concerned about the administrative costs of doing so, agency might provide a resolution to their dilemma. As stated earlier a right founded on agency may be excluded by statute; that it may be so is not so clear if the right is founded on natural justice. ${ }^{25}$ Hence if the courts established a right based on agency, they would leave it open for the government to overrule them should the cost seem excessive.

The principle is easier to state in the natural justice context to which I wish to turn. Moreover, given the vagueness of the "manifestly improper person" requirement, the success of the agency argument may turn out to depend on the resolution of issues that natural justice questions raise; such as the nature of the proceedings and the interests involved. In this context the first question is whether natural justice in any circumstances requires a right to legal representation. The textbooks are uncertain on this. Wade feels it is "not clear" that a right to legal representation is established as part of natural justice; ${ }^{26}$ Garner more optimistically states it is not clear in "precisely what circumstances it may be a breach of natural justice to deny a person an opportunity to be represented by his lawyer". ${ }^{27}$ As for the more specialist accounts, Flick suggests that the right to counsel is not an established part of natural justice but that a tribunal always has a discretion to allow it, ${ }^{28}$ while Jackson, without committing himself to any position, notes that courts have often emphasised the right to representation but rarely granted it. ${ }^{29}$

This uncertainty is perhaps excusable when one considers the caselaw available. Apart from the prison cases themselves, the issue of a right to legal representation has arisen in four other decisions concerned with disciplinary hearings over the past 20 years. In the first of these, Pett v Greyhound Racing Association, ${ }^{30}$ Lord Denning MR announced clearly that "when a man's reputation or livelihood is at stake, he not only has a right to speak by his own mouth. He also has a right to speak by counsel or solicitor". ${ }^{31}$ However, this statement appeared in the context of a discussion of the agency argument and, while Lord Denning later reiterated in the course of the same judgment that natural justice required a right to legal representation where the tribunal dealt with matters of "serious import", some ambiguity remains over his foundation for this right. This ambiguity is compounded by the fact that although the other two judges concurred in the decision, Russell LJ refers only to agency in upholding a right to representation.

25 See the discussion in Cane, Introduction to Administrative Law (1986), p 105.

26 Administrative Law (5th ed, 1982), p 485; Craig Administrative Law (1983), p 276 also pronounces himself "not clear" whether natural justice can require a right to representation.

27 Administative Law (6th ed, 1985), p 145 n 11.

28 Natural fustice (1979), pp 147-8.

29 Natural fustice (2nd ed, 1979), p 74.

30 [1968] 2 All ER 545.

31 Ibid, at p 549. 
Pett was a decision only on an interlocutory application. When the issue of whether the Greyhound Racing Association could begin disciplinary proceedings against one of its members without allowing him to be legally represented came to trial, Lyell J disagreed with the Court of Appeal. His decision in Pett No $2^{32}$ was heavily influenced by the Privy Council decision in University of Ceylon $\mathrm{v}$ Fernando. ${ }^{33}$ There the Court had concluded that, at least as regards a private tribunal set up under contract and invested with quasi-judicial functions, the only obligation was to conduct the proceedings in accordance with "elementary and essential principles of fairness" ${ }^{34}$ Lyell J decided that this did not mean there could exist a right to legal representation, as he stated: "I find it difficult to say that legal representation before a tribunal is an elementary feature of the fair dispensation of justice. It seems to me it arises only in a society which has reached some degree of sophistication in its affairs". 35 As Alder has commented this is a strange reading of the Fernando decision. This has generally only been cited as authority for the proposition that the content of natural justice is not invariable. ${ }^{36}$ At most it indicates that a right to legal representation will not exist in every situation where natural justice or the duty to act fairly applies, but who ever argued that it did? Moreover, Fernando employs the now discredited terminology of "quasi-judicial functions" to reach its conclusion. Were the tribunal under a "judicial" duty, no doubt different procedures would be mandated, including, perhaps, a right to legal representation. More modern approaches find these categorisations inadequate to explain the content of natural justice in any particular case. ${ }^{37}$

Despite these weaknesses, Pett No 2 was not challenged by the Court of Appeal in its decision in Enderby Town Football Club v Football Association. ${ }^{38}$ There a football club sought legal representation at a hearing at which it was charged with gross negligence despite a rule of the Association which prohibited such representation at such hearings. Lord Denning MR reinterpreted his original Pett decision in the light of Pett No 2 to say that there the Court had not recognised a right to representation but rather had decided that the tribunal had a discretion to grant representation and had exercised it unreasonably. Deciding on the question of a right to representation, he invoked Collier v Hicks to say that he doubted that it had ever existed before domestic tribunals. The limitations of this argument have already been alluded to but it seemed enough to persuade the other members of the Court as they devoted most of their argument, not to the issue of a right to representation, but to whether the tribunal could by the rules exclude even a discretion to allow representation. This they concluded was fair given that allowing lawyers

32 [1969] 2 All ER 221.

33 [1960] 1 All ER 631.

34 Ibid, at p 639.

35 [1969] 2 All ER 221, 231.

36 Op cit supra $\mathrm{n} 15$, at $\mathrm{p} 283$.

37 See the discussion of the move away from this categorisation approach at text accompanying notes $51-54$.

38 [1977] 1 All ER 215. 
would unnecessarily increase the cost and length of proceedings, that the tribunal was composed of people of great experience in the administration of football, and that any difficult points of law could be resolved by application to the court. This does not amount to a full consideration of whether natural justice can ever require legal representation; at most it tells us that some domestic tribunals, hearing matters not involving people's liberty or livelihood, may do so fairly without allowing lawyers to be involved. Indeed, at times in his judgment Lord Denning seems to think that the argument for a right to representation was based on agency. If it were, the rule of the association prohibiting representation would automatically exclude it.

The fourth case, Maynard v Osmond, ${ }^{39}$ comes closest to prison disciplinary hearings as it involves a disciplinary hearing in the police force where regulations permitted a junior officer to be represented by a senior officer at a hearing before the Chief Constable. The plaintiff sought a declaration that the rules entitled him to be legally represented or, if they did not, that they violated natural justice. The Court of Appeal refused to grant relief. While Lord Denning MR felt that "in principle" a man facing a serious charge should be entitled to legal representation, Orr $\mathrm{LJ}$ found no authority that either denial of a right to legal representation or a discretion to grant it constituted a breach of natural justice. However, all three judges were satisfied that fairness would be complied with as the constable could be represented by a senior police officer who could defend him as well as a lawyer. Indeed Lord Denning stated: "He will probably do it better than a lawyer because of his knowledge of the inner workings of the police force" ${ }^{40} \mathrm{Like}$ the Enderby Town case this decision essentially states that legal representation is not always necessary; indeed rare will be the occasions where it is required. It does not, however, clearly state that natural justice can never require legal representation and suggests a need to examine closely the circumstances of each particular decision.

This, however, does not appear to me to have occurred in the prison discipline cases. In the first of these, Fraser v Mudge, Lord Denning MR's rather brusque judgment appears to offer only two reasons for rejecting the claim of a prisoner to a right to legal representation. First, that recognising such a right would lead to delay in hearing charges of alleged breaches of discipline, something unacceptable in a situation where the whole emphasis must be on speed and finality; and, secondly, that prison disciplinary hearings were analogous to those in the army or navy where it was clear that legal representation had never been allowed. Both of these assumptions must be regarded as suspect after $S_{t}$ Germain. There, the Court of Appeal were very much of the view that delay or administrative inconvenience alone were no grounds for depriving people of their legal rights. As regards what has been called the "military 
model" 41 of prison disciplinary procedure, they suggested that whatever value it might have in illuminating the nature of governors' hearings it was a misplaced analogy where proceedings before the Board of Visitors were concerned.$^{42}$ Roskill LJ, who agreed with Lord Denning in Fraser, offered two additional reasons for denying a right to representation. First, that it was not true that in every hearing before a tribunal legal representation was required for justice to be done or seen to be done. This may well be correct but it does not say that legal representation is never required or tell us how to go about deciding before which sorts of tribunals representation is, or is not, required. Secondly, that if representation were allowed before a Board, it could not be refused before a governor. As Tarrant decided, this is not a necesary conclusion for a natural justice analysis.

Given that in addition to these flaws in the judgment, Fraser was an unreserved judgment-given in a case on an ex parte application, on the same day as the Divisional Court had refused the application and only a few hours before the Board of Visitors' hearing was about to take place-one might doubt its having authoritatively settled such an important point. Nevertheless, the Divisional Court in Tarrant, perhaps influenced by the fact that it was a Court of Appeal precedent, adopted it without much discussion. It is not clear whether a higher court would show such respect. The Northern Ireland Court of Appeal took a similar approach in In re Hone and McCartan's applications where Lord Lowry LCJ found no authority for a right to representation and rejected an argument based on Lord Denning's Pett formulation on the grounds that recognising such a right in every case of "serious import" would lead to great uncertainty. It is arguable whether recognising such a right in the context of Board hearings would lead him to formulate a proposition of such width. The closest which any of these decisions comes to a discussion of the right to legal representation in the specific context of prison discipline is perhaps the view that Kerr LJ inTarrant when he stated-

it cannot for one moment be accepted on the authorities that in all proceedings whether of an adversarial or inquisitorial nature with potentially grave consequences for the persons concerned, the principles of natural justice impose any obligation on the tribunal or body in question to allow legal representation automatically on request. In many cases this would not only be unnecessary but counter-productive. ${ }^{43}$

As I hope to show below, this statement contains the seeds of an approach which could resolve the issue of what natural justice does

41 See Fitzgerald, Prison Discipline and the Courts in Accountability and Prisons (ed Maguire, Vagg and Morgan, 1985), pp 29-45.

42 Indeed it has been rejected by the Northern Ireland Court of Appeal as an appropriate analogy even where governor's disciplinary hearings are concerned: see $R$ v Governor HM Prison Maze, ex parte McKiernan (1986) 6 NIJB, discussed in Livingstone, "Prisoners Rights in Northern Ireland" (1986) 36 NILQ 75. In In re Hone and McCartan's Application (1986) 8 BNIL Lord Lowry LCJ made it clear that Board disciplinary hearings could not be equated with those in the police or armed forces. 
require in prison disciplinary hearings. As has already been seen in Enderby Town and Maynard v Osmond, the courts may conclude that legal representation would be counter-productive in particular circumstances. What Kerr LJ fails to do is to apply these principles to the particular circumstances of prison disciplinary hearings. What I hope to demonstrate below is that, when fully expanded, application of these principles does suggest that a right to legal representation is part of a fair procedural regime in these hearings.

Before moving on to this task it is worth clarifying that the courts do recognise that in some circumstances natural justice does require the right to be legally represented. This can be gleaned negatively from Kerr LJ in Tarrant (legal representation not available "in all cases") but more positively from the Privy Council decision of Haw Tau Tau v Public Prosecutor $^{44}$ where Lord Diplock stated that natural justice must move with the times and that the procedure for trial of criminal offences in England had at various periods-

involved practices, particularly in relation to the trial of felonies, that nowadays would unhesitatingly be regarded as flouting fundamental rules of natural justice. Deprivation until 1836 of the right of the accused to legal representation at his trial and, until 1898, of the right to give evidence on his own behalf are obvious examples. ${ }^{45}$

Further support for this view can be derived from contempt of court cases, most recently $R$ v Newbury $\mathcal{F}$ ustices ex parte Pont ${ }^{46}$ where May LJ, while upholding the justices committal of 11 women to prison without legal representation, felt the argument based on natural justice was a point of substance. He rejected it only because he felt that this was a serious contempt in the face of the court which prevented it from carrying on its business and had to be dealt with swiftly. The need for speed, in order to restore order in the court on the particular day the contempt occurred, is obviously of a different order from that involved in prison disciplinary hearings but I shall return to this point.

These two cases suggest that a right to legal representation can be part of a fair procedure. They do not clearly establish this to be necessary in prison disciplinary hearings and, indeed, as I have already shown, many cases can be cited which suggest the opposite ${ }^{47}$ If the discussion on natural justice has shown anything so far, it is that mere citing of precedents is unlikely to decide whether it requires a right to legal representation in Boards of Visitors' hearings. What is needed is perhaps a return to basics and an attempt to examine Boards of Visitors' hearings

44 [1982] AC 136.

45 Ibid, at $\mathrm{p} 154$.

46 (1984) 78 Cr App R 255.

47 Commonwealth decisions finding no right to legal representation in prison discipline hearings are $R$ v Pentridge Visiting $f$ ustices, ex parte Walker [1975] VR 883 and $R e$ McLeod and Maksymowich (1973) 38 DLR (3d) 251. For one decision, in a police discipline case, finding that natural justice did not require legal representation see $R e$ Bachinsky et al and Sawyer (1973) 43 DLR (3d) 96. 
in the context of general principles as to the content of natural justice or its modern equivalent of "fairness". Such an approach appears to me to have been lacking in litigated cases on Board hearings so far.

Admittedly this is not an easy task as there has been quite lively controversy among academic writers as to what sort of theory does or should explain the applicability and content of natural justice. ${ }^{48} \mathrm{How}-$ ever, over the last few years some sort of consensus has evolved around a few basic propositions.

The first of these is that whether a duty to act fairly exists does not depend on categorising the decision as "judicial" or "administrative", or upon categorising the right of the individual affected as a "right" or a "privilege". Rather, the correct approach is the initially somewhat more vague approach of Lord Reid in Ridge v Baldwin ${ }^{49}$ wherein he suggested that the applicability of natural justice will depend on the nature of the power exercised (is it of the sort appropriate to judicial control via procedural protections) and its effect on the individual concerned (is it potentially serious enough to warrant judicial involvement). The second proposition is that in keeping with the movement from the articulation of "the rules of natural justice" to the modern "duty to act fairly in all the circumstances", 50 procedural protections do not apply in an all-ornothing way. Simply because we decide that a duty to act fairly exists in a particular situation this does not automatically mean that an individual involved is entitled to the full panoply of procedural protections, such as a right to notice, a hearing, reasons and legal representation. Rather there exists a continuum ranging from a right to an unbiased decisionmaker at one end to a procedural regime akin to a criminal trial at the other. Whether we say that at the lower end of this continuum there exists a duty to act fairly while at the upper end natural justice applies, or that the duty to act fairly varies with the circumstances and encompasses both poles, it comes to the same thing. Hence just as the question of when fairness applies is not dependent on a matter of categorisation, neither is its content. Indeed, where a particular type of decision lies along the spectrum, and thus what procedural protections are mandated, depends on a variety of factors. A third proposition which appears to follow from the above is that determining the content of natural justice in any particular situation will therefore involve the court to some degree in a balancing exercise.

Some commentators have moved beyond recognising the existence of such balancing to attempting to spell out the relevant factors which must be balanced. Perhaps the most notable among these is Craig, ${ }^{51}$ who points to three relevant factors. The first of these is the individual interest

48 See the discussion of this in Harlow and Rawlings, Law and Administration (1984), pp 78-94.

49 [1964] AC 40.

50 See, eg, the speech of Lord Scarman in Council of Civil Service Unions v Minister for the Civil Service [1984] 3 WLR 1174.

51 Op cit supra n 26, pp 265-73. 
at stake. Denuded of their determinative character, questions of whether the individual's interest is a "right", a "privilege" or an "expectation" may have a role to play when weighed against other factors. The second factor is the benefit to be derived from additional procedural safeguards. This appears to turn on how closely the nature of the decision resembles traditional two-party adjudication before an impartial third-party over a matter of rights. The more it does so, the more procedural protections derived from traditional adjudications will be appropriate. Where, however, it resembles inquisitorial proceedings or even more so "polycentric"s2 disputes involving several parties and interests, it must be questionable whether procedure derived from the adversary mode of criminal and civil procedure benefits anyone. The third factor is the costs to the administration, both direct and indirect, of complying with additional procedural safeguards. If these are particularly high, in financial or labour terms (hence necessitating the diversion of resources from other functions or duties of the administration) then the safeguards may have to be forgone.

This formulation, or rather the very similar formulation for the content of procedural due process adopted by the United States Supreme Court in Matthews v Eldridge, ${ }^{53}$ has not gone without criticism. Mashaw $^{54}$ in particular has suggested that without adequate standards against which to balance factors courts will engage in a form of utilitarian calculus. Yet finding a common unit of measurement by which to weigh additional administrative costs and increased individual safeguards is a notoriously difficult task. Finding it so, courts are likely instead to devise an informal hierarchy of interests and procedures. Such a ranking, even as a prima facie measure, raises the possibility of once again, for example, categorising disputes over property rights as automatically appropriate for adversary procedures and those over other interests as automatically requiring other procedures or none at all—exactly what balancing was meant to avoid. My purpose in this paper, however, is not to engage with these criticisms but rather to investigate whether, if Craig and others are right as regards this balancing approach equating to current judicial practice, it requires certain forms of procedure in Boards of Visitors' hearings, and in particular whether it requires a right to legal representation.

Applying this approach to Boards of Visitors' hearings, it appears that the first question-whether fairness in its broadest sense applieshas been resolved positively ever since St Germain. Two attempts to exclude it appear largely to have failed. The first of these invoked the right/privilege distinction and suggested that since remission was not a

52 The term is derived from Fuller, "The Forms and Limits of Adjudication" (1978) 92 Harv LR 353.

53424 US 319 (1976).

54 See Mashaw, "The Supreme Court's Due Process Calculus for Administrative Adjudication in Matthews v Eldridge: Three Factors in Search of a Theory of Value" (1976) 44 Univ of Chicago LR 28. 
right no procedural protections were needed against its loss. This has received increasingly short shrift in recent cases. ${ }^{55}$ The second attempt suggested that prison disciplinary hearings were analogous to those in the armed forces with the Board exercising similar powers over prisoners to a commanding officer over his men. This "military model"56 essentially excludes the rule of law by suggesting that the legitimacy of power derives from authority and that any challenge to authority, including that founded on judicial review, endangers the stability of the institution. This type of argument found favour with Lord Denning in Fraser $\mathbf{v}$ Mudge and continues to be invoked in England, though not Northern Ireland, in cases involving governors' disciplinary powers. ${ }^{57}$ In general, it is a strange argument for whereas in the armed forces men willingly join the services, agree to be under the command of their officers, and work towards a common purpose, few would describe this as true of the relationship between prisoners and the prison authorities. Their contact is brought about entirely through the law. As Lord Lowry LCJ stated in McKiernan, if anything it is the prison officers which constitute the disciplined body of which the governor is the head..$^{58}$ It is, as the $S t$ Germain court accepted, an even stranger argument in the context of Board hearings in which the Boards simply adjudicate on disputes and order punishments- they are not in the business of daily giving orders to prisoners or running the prison. Elements of the "military model", especially the need for speed in adjudications, reappear in the "cost" part of the equation below. There, however, they are merely a factor to be considered in assessing the content of procedures judicially mandated, not a reason for excluding judicial review entirely.

The real issue, therefore, is the content of natural justice in Board hearings. To turn to the first of the factors to be balanced, that of the nature of the interest affected, it now appears to be generally accepted that loss of remission is a very serious penalty. Involving as it does prisoners spending longer in prison than they otherwise would, it may not technically be a loss of liberty but becomes effectively to the prisoner the equivalent of another sentence. It is worth pointing out that in all hearings before Boards in England, Wales and Northern Ireland the prisoner faces a potential six months loss of remission, equivalent to what a Magistrates' Court can award for most offences. Were he charged before a Magistrates' Court for the same offence, he would be entitled

55 See, eg, the view of McCullough J in $R$ v Highpoint Prison Board of Visitors, ex parte McConkey, The Times, 23 September 1982 where he states that whether a man is deprived of a "right" to liberty by the courts or a "privilege" of remission by a Board it comes to much the same thing, "a man who would otherwise be free was in prison".

56 See Fitzgerald, op cit supra n 41, for an explanation of this.

57 Compare In re McKierman's application supra $\mathrm{n} 42$ with $R$ v Deputy Governor Camphill Prison, ex parte King [1985] I WLR 36.

58 Indeed there has perhaps in these cases been a conflation of the terms "disciplinary hearing" and "disciplined body". The two are not synonymous; professional organisations and political parties among other institutions have disciplinary hearings of the institution but are not "disciplined bodies" in the sense of tight knit organisations where uncritical obedience to superiors is required. 
to full procedural protection including a right to legal representation. 59

The second factor, the nature of the hearing, is particularly important in prison disciplinary hearings. Some attempts have been made to suggest that Board hearings are "inquisitorial" in nature,${ }^{60}$ that the Board is attempting not merely to determine the prisoner's guilt or innocence, but also to assist its "pastoral" role in investigating discontent in prison, and hence that adversarial procedure is inappropriate. However, these attempts have now largely been relinquished. As Fitzgerald ${ }^{61}$ points out, decisions spelling out the content of charges, ${ }^{62}$ specifying the burden of proof, ${ }^{63}$ and denying Boards the power to alter charges without proper notice ${ }^{64}$ have effectively removed any power in the Board to make decisions in disciplinary proceedings on the basis of what is in the best interests of the prison or prisoner. ${ }^{65}$

However, while it is thus accepted that these proceedings resemble criminal hearings and thus that the procedures developed in the adversarial mode of criminal trial are appropriate to them, it has perhaps been underestimated how important the additional procedural protection of legal representation might be. Two aspects of Board hearings bring this out.

The first was highlighted by the United States Supreme Court in Wolff $\mathrm{v}$ McDonnell. ${ }^{66}$ There the Court noted that whereas in criminal hearings prosecution, witness, defence and tribunal may never see each other again after the hearing, in prisons these participants are likely to remain in close, perhaps daily, contact, regardless of the outcome. Statements made and attitudes struck during the hearing may sour relations after it. Just as significantly, perhaps, awareness of this possibility may affect behaviour during the hearing. Prisoners may, for example, refrain from asking questions or vigorously pursuing cross-

59 See s 122(1) Magistrates Court Act 1980; art 164(1) Magistrates Court (NI) Order 1981 SI $1981 / 1675$. Perhaps it has also been assumed too easily that lengthy periods of solitary confinement are not a serious penalty. When introducing the 1964 Prison Rules the Home Secretary described solitary confinement as a "severe penalty": 687 $H C$ Debs col 1410 (23 January 1964).

60 See the discussion of this by Webster J in Tarrant [1984] 1 All ER 799, 812.

61 See Fitzgerald, op cit supra n 41.

62 See, eg, $R$ v Highpoint Prison Board of Visitors, ex parte McConkey, The Times, 23 September 1982, and $R$ v Deputy Governor Camphill Prison, ex parte King [1985] 1 WLR 36.

63 See Tarrant [1984] 1 All ER 799.

64 See $R$ v Dartmoor Prison Board of Visitors, ex parte Smith [1986] 3 WLR 61.

65 See $e g$, the recent decision of $R \vee$ Frankland Prison Board of Visitors, ex parte Lewis [1986] 1 All ER 272. In this, a case where it was suggested that the fact a Board member had previously been involved in a decision on a prisoner in his "administrative" capacity gave rise to suspicions of bias when he later came to adjudicate a charge against the same prisoner, Woolf J rejected the application but added (at $\mathrm{p} 274$ ) that in adjudications the Board was acting in a "judicial capacity and is under a duty to conduct its proceedings in a judicial and fair manner". 
examination of prison officers out of a sense that the value of an acquittal on a charge may quickly be nullified by their subsequent treatment by aggrieved prison officers who control nearly all aspects of the prisoner's life. The Supreme Court reacted to this by refusing a right to crossexamine (something the English courts did allow in $S_{t}$ Germain (No 2)) on the grounds that this would introduce a hostile and adversarial element into hearings. Yet surely this is to ignore the reality that such hearings are adversarial and that what the courts and other institutions should be doing is to find ways of minimising the harmful effects of this. In particular, they should be seeking methods whereby the weaker party to the confrontation can assert his rights without risking punishment for doing this. While prisons may often work on shifting power relations and alliances between officers and prisoners, ultimate power always remains with the former. Ensuring legal representation for prisoners means that vigorous questioning is more likely to be pursued from the prisoner's side and perhaps less likely to be perceived as a personal attack on the character or integrity of the witness, it coming from a lawyer employed to do the job rather than the defendant himself.

The prisoner presenting his own case may be disadvantaged in another way. In McBarnet's study ${ }^{67}$ of unrepresented defendants in the magistrates court she suggests that defendants who actually did put up a vigorous defence, who presented the kinds of arguments a good lawyer would, were less likely to be perceived as doing this than as in some way trying to undermine the authority of the court. Well placed questions were often seen as attempts to "be clever", deliberately show up police officers as fools, or waste the court's time. How much more likely is this to occur with prison disciplinary hearings where at least some prisoners have an interest in undermining the institution, the tribunal will be dealing with convicted prisoners rather than potentially innocent members of the public, and, if anything, its members may have even less experience of good defence advocacy than benches of magistrates. ${ }^{68}$ Since the Board may find it difficult to separate the prisoner as advocate from the prisoner as defendant, it may be better to do this for them by entitling the prisoner to an advocate.

In conclusion on this part of the equation it can be said that, unlike the Enderby Town case, these hearings are not concerned with broad matters such as the interests of the game, where the narrowing of focus which lawyers bring might be unwelcome. Nor, unlike Maynard $\mathbf{v}$ Osmond, is there someone readily available who could put the prisoner's

67 Conviction: Law, the State and the Construction of Justice (1981), chapter 7.

68 Unfortunately the empirical survey conducted by the Home Office on Board Hearings does not address itself to whether similar problems exist in prison. It did find though that in general prisoners regarded the standard of justice at Board hearings as about equivalent to Magistrates' Courts and worse than the higher courts; see Austin, Ditchfield and Smith, "Board of Visitors Adjudications" Home Office Research Unit Paper 3 (1981). This view appeared largely to be confirmed by the study carried out for Prior, op cit supra $\mathrm{n} 8$, vol 2, appendix 11. For a more critical view of Board hearings see Fitzgerald \& Sim, British Prisons (2nd ed, 1982), pp 78-82. 
case better than a lawyer. ${ }^{69}$ The difficulties for a prisoner in putting his own case have hopefully been shown.

The third issue is that of cost. This weighs against representation as indeed it will always weigh against any increase in procedural protections. As Mashaw ${ }^{70}$ has noted, cost is difficult to calculate, especially for courts which may not have all the relevant evidence. The general cost of additional procedures is time, both greater delay in hearing cases and more time spent in hearing each case, especially if lawyers are present to invoke technical points. It seems undeniable that allowing a right to legal representation would have this effect. Figures produced for the Prior Committee showed that where legal representation was granted the average period between charge and hearing rose to 12 weeks. ${ }^{71}$ The Home Office reply to Prior included statistics showing the average length of time spent in hearing a case where legal representation had been granted was 166 minutes as opposed to 35 minutes where the prisoner was unrepresented. ${ }^{72}$ These delays could, however, be reduced by granting a right to representation rather than the existing discretionary system as, first, the need for a preliminary hearing on whether or not to grant representation would be avoided, ${ }^{73}$ and, secondly, more solicitors might be encouraged to gain experience of these hearings, hence reducing the need to hold them at a time convenient for the few existing specialists. ${ }^{74}$ Some increase in delay does seem likely, however, if prisoners were to exercise any right to representation.

To evaluate more precisely the additional costs it is perhaps worth trying to break down more precisely the potential effects of increased procedures, in particular a right to legal representation.

The first of these costs is that increased delay could weaken the Board's function of swiftly restoring order and maintaining discipline in the prison. However, it is doubtful if this is really its function at present. Even without representation most hearings occur several weeks after the events to which they relate. The governor's power to hear charges the day after events occur seems much more apposite to this task. ${ }^{75}$ When one considers that only around 5 per cent of charges are heard by Boards, it

69 Prior offered no alternatives. Prison Officers and Probation Officers who appear to be the only likely candidates both seem unwilling to become involved in this way and it is not clear that they would be acceptable to prisoners.

70 See Mashaw, op cit supra n 54, pp 45-6.

71 See Prior Committee, op cit supra n 8, vol 2, appendix 10 table 5.

72 The Prison Disciplinary system in England and Wales (Cmnd 9920, 1986), annex B.

73 The development of "filtering panels" to hear applications for legal representation is discussed by Morris, "Boards of Visitors and Judicial Review: The Importance of Practice" 150 Justice of the Peace 22 Nov 1986, p 729.

74 This will perhaps be encouraged by the fact that legal advice and assistance by way of representation is now available where a prisoner has been granted legal representation in a disciplinary hearing before a Board. See Legal Aid, Advice and Assistance (NI) Order 1981 SI 1981/228), art 17(3) as amended by Legal Advice and Assistance (Amendment) Regulations (NI) 1984, SR 1984/82.

75 Hence it is much more difficult to argue for a right to legal representation at governors' hearings. 
seems more likely that they are used in much the same way as criminal courts outside prison, that is because they can hand out quite severe punishments which deter future serious misconduct. Increasing the time taken before they hear cases does not affect this function.

A second species of costs is the simple pecuniary costs of more hearings which take longer, in terms of lawyers' fees and Board members' expenses. This, however, need not be large and 35 minutes does seem a rather short time in which to adjudicate on charges carrying serious penalties, especially if these are contested.

A third and more significant set of costs is the indirect effect of more elaborate hearings on general prison life. This, as I hope to show, much influenced the Prior Committee and recently Morris has suggested that the legalisation of prison discipline may not necessarily always improve the prisoner's lot. ${ }^{76} \mathrm{~T}$ wo aspects are important here: first, that a lengthy delay before hearing may lead prisoners who have been charged to spend more time in segregation with a consequent increase in tension, ${ }^{77}$ and, second, that more formal hearings will necessitate prison officers making more detailed statements and spending more time at hearings. This could divert staff resources from activities like supervising work, education and recreation. These are problems but again may not be as large as they initially seem. The Prior Committee made recommendations to reduce pre-hearing segregation, ${ }^{78}$ while, given the overcrowding and strain on resources in many prisons anyway, prisoners may feel a perceptibly fair disciplinary system, especially where substantial amounts of remission are involved, compensates for slight losses in other areas of prison life.

To conclude on this issue, I hope I have shown, first, that no cases clearly establish that a right to legal representation can never be a part of the content of natural justice, or the duty to act fairly. On the contrary, several cases suggest that where serious interests, notably liberty, are at stake, where the nature of the procedure is akin to the adversarial criminal trial, and where the costs of representation are not too high, it will be mandated as part of a fair procedure. Secondly, I hope I have demonstrated that Boards of Visitors' hearings do lie at that end of the continuum of the content of natural justice. Personal liberty is at stake, the procedure is now accepted to be essentially adversarial and on the issue of costs it is far from conclusive that these would be excessive if a right to representation were granted. I also hope I have demonstrated that there are structural and administrative reasons which support the

76 See Morris, op cit supra $\mathrm{n} 73$.

77 Currently under prison rule 29(2) in Northern Ireland a prisoner charged with an offence against discipline may be kept apart from other prisoners pending adjudication. As Morris notes (op cit supra $n$ 73) this is now used largely as a matter of routine.

78 Prior, op cit supra $\mathrm{n} 8$ recommended that the new Prison Discipline Tribunal be involved in pre-hearing segregation. This recommendation has not been accepted by the Government: see Prison Disciplinary System in England and Wales supra n 72, para 63. 
view that this should be a right rather than a matter for the discretion of the Board as at present. Hearings before the Board of Visitors seem to be the sort of occasion the American Supreme Court had in mind when it stated in Powell v Alabama: "The right to be heard would be in many cases of little avail if it did not comprehend the right to be heard by counsel". ${ }^{79}$

\section{THE EUROPEAN DIMENSION}

Article 6(3) of the European Convention on Human Rights ${ }^{80}$ states that everyone charged with a "criminal offence" has the right "to defend himself in person or through legal assistance of his own choosing". At first sight this does not seem likely to be of great help to prisoners charged with offences under the prison discipline code. However, in 1976 the European Court in Engel $\mathrm{v}$ Netherlands ${ }^{81}$ decided that simply because a state defined a charge as "disciplinary" that did not decide matters as regards the Convention. Rather such a charge could be "criminal" for the purposes of Article 6 depending on three factors: first, whether the charge existed purely in the disciplinary law of the state, or whether it existed concurrently in the disciplinary and criminal law; secondly, the nature of the charge; thirdly, the severity of the potential penalty. As the Court subsequently confirmed, the latter two factors were the most significant. ${ }^{82}$

Engel concerned disciplinary charges in the armed services but six years later the Commission, ${ }^{83}$ and subsequently the Court, ${ }^{84}$ concluded in Campbell and Fell $\mathrm{v}$ United Kingdom that such principles applied to prison disciplinary hearings. Applying these principles to the cases before them, the Commission and the Court concluded that Article 6(3) applied to rule 52 mutiny charges in England and Wales. I have argued in a previous edition of this journa ${ }^{85}$ that the scope of the Court's Campbell decision is unclear and could encompass a right to representation in most Boards of Visitors' hearings in both Northern Ireland and England and Wales. In Campbell a key aspect of the decision appeared to be the Court's view that loss of remission could, by causing detention to continue "substantially longer", come close to constituting deprivation of liberty, the Engel Court having previously concluded that punishment involving deprivation of liberty generally belongs in the criminal sphere. What is unclear is exactly how much potential loss of remission amounts to "substantially longer detention" and, more precisely, whether a potential 180 days loss is enough.

79287 US 45, 68-9 (1932).

80 (Cmd 8969, 1950).

81 (1976) 1 EHRR 647.

82 See Ozturk v Germany (1984) 6 EHRR 409.

83 (1982) 5 EHRR 207.

84 (1985) 7 EHRR 165.

85 See Livingstone, op cit supra n 42. 
One obstacle to saying 180 days is enough is that the Commission explicitly refused in Kiss $\mathrm{v}$ United Kingdom ${ }^{86}$ to hold that a charge carrying a potential 180 days loss was "criminal" within the meaning of Article 6(3). Moreover, the Commission in Campbell cited Kiss and inferred from it that because the potential penalty in the Campbell case was unlimited, as opposed to the 180 day maximum in Kiss, a conclusion that it could not amount to a "criminal" penalty was incorrect. However, the Campbell Court did not make this point and the Commission and the Court have disagreed before. ${ }^{87}$ One argument against seeing Kiss as a clear authority on this point is that there the Commission was essentially only concerned with whether any loss of remission constituted loss of "liberty" within the meaning of Article 5. Hence it could be argued that the issue of the significance of the potential penalty being 180 days loss of remission (as opposed to the 28 days potential loss in governor's hearings, for example) has never properly been raised.

One further obstacle to seeing Article 6 as requiring a right to representation in all Boards of Visitors' hearings is that not all charges may satisfy the "nature of the charge" requirement. While some charges, such as assault or doing gross personal violence, are offences under the general law, other charges in the prison disciplinary code, such as "repeatedly making groundless complaints", 88 appear, and have meaning, only in that code. If the severity of the penalty is not the only relevant factor in invoking Article 6(3), then not all charges before Boards would entitle a prisoner to legal representation according to the Convention. The Court might, however, consider that where the penalties and punitive nature of the charges are identical it would be wiser not to perpetuate anomalies as regards the procedure.

This brief survey of the European position suggests that there may be as great, if not greater, difficulties in establishing a right to legal representation before all Boards of Visitors' hearings under Article 6(3) of the Convention as there are in domestic law. This makes it all the more important to consider how domestic courts have viewed the exercise of the discretion to grant such representation.

\section{TARRANT AND THE DISCRETION TO GRANT REPRESENTATION}

While affirming the rejection of a right to legal representation, the Divisional Court in Tarrant found that the Board, as masters of their own procedure, had a discretion to allow representation either by a lawyer or someone else (apart from another prisoner). Moreover, this was not unfettered discretion but rather one which had to be exercised according to certain guidelines. Webster J went on to specify six factors which

867 D \& R 55.

87 See, eg, in Campbell and Fell itself where the Court disagreed with the Commission's conclusion that the Board of Visitors was not an "Independent Tribunal" within the meaning of Article 6(1).

Rule 47(16) Prison kules 1964, rule 31(16) Prison Rules (Northern Ireland) 1982. 
Boards should take into account in deciding whether or not to grant representation. These were: (1) the seriousness of the charge and potential penalty; (2) whether any serious points of law were likely to arise; (3) the capacity of a particular prisoner to conduct his own defence; (4) the difficulties for a prisoner in preparing a defence, particularly in tracing and interviewing witnesses, if he were segregated prior to the hearing under rule $48(2) ;{ }^{89}(5)$ the need for reasonable speed in making adjudications; (6) the need for fairness as between prisoners and as between prisoners and prison officers. As the Board had failed to exercise its discretion in any of these cases, all its decisions were quashed.

Tarrant undoubtedly represents a major breakthrough in establishing the rule of law in prison disciplinary hearings. The decision has been praised as a "tribute to the resources of the common law" in that the court managed to produce a result doctrinally in harmony with $F$ raser v Mudge while rejecting that decision's overall thrust as to the undesirability of legal representation in prison disciplinary hearings. The enunciation of the six Webster factors left the position interestingly poised for the future; would the courts state that if the Board had taken these into account they were immune from further review in any case in which they had refused representation, or would they specify more clearly when operation of some or all of the six factors made it unreasonable to refuse representation, and thus eventually create a de facto right to representation. Examination of the few occasions thus far when the courts have been called upon to consider the application of the Webster criteria suggests that they will follow neither approach exclusively but that rare will be the occasions when a Board will be held to have acted wrongly in refusing representation. ${ }^{91}$

In Tarrant itself Webster $\mathrm{J}$ stated that while the Board had a discretion they must exercise it reasonably, taking into account the six factors and the overriding obligation to ensure that the prisoner received a fair hearing. Considering the individual cases litigated in Tarrant, he concluded that no reasonable Board could refuse to grant representation to a prisoner on a rule 52 mutiny charge. This resulted from considerations of the complexity of the charge at issue, involving as it did notions of collective action towards a common end, and the potential penalty faced, namely unlimited loss of remission. However, Webster J concluded that a Board properly exercising its discretion could reasonably refuse to grant representation where a prisoner faced a rule $51(1)(b)$ charge of assaulting an officer. In the subsequent case of $R$ v Board of Visitors HM Prison Blunderstone, ex parte Norley ${ }^{92}$ Webster J reached a

89 Rule 29(2) in Northern Ireland.

90 See Fitzgerald, op cit supra n 41, p 37.

91 Such an outcome is perhaps foreseen by Lewis, "Prisoners and Legal Representation" (1984) PL 401, 402 where he sees the emphasis on the tribunal's discretion in Tarrant as "harking back to the pre Ridge $\mathrm{v}$ Baldwin era when courts stressed that bodies were masters of their own procedure subject only to residual (and rarely used) control by the courts".

92 Unreported, 4 July 1984. 
similar conclusion where a prisoner faced a rule $51(1)(c)$ charge of doing gross personal violence to someone other than an officer. In Norley Webster J returned to and further explained several of the Tarrant factors to be taken into account by a Board (and made it clear that this was not to be regarded as an exhaustive list). In particular, he stated that merely because an offence fell within the rule 51 "graver offence" category this would not automatically entitle one to representation but was only a factor to be taken into account by the Board. In reply to the argument that the applicant's defence, one of self-defence, involved difficult questions of law, including the burden of proof, and that this weighed in his favour on the issue of representation, Webster J replied that in this particular case the content of the defence involved simple factual matters such as who struck whom and that a lawyer was not necessary to present these. Finally, he rejected the prisoner's claim that he was incapable of conducting his own defence as he lacked a lawyer's skill in crossexamination. Webster J concluded that professional cross-examination of all witnesses was not necessary to ensure a fair hearing and said that this prisoner was "articulate and intelligent". ${ }^{93}$

The outcome of these two decisions would appear to be that while there is now a right to representation on rule 52 charges (certainly on mutiny charges), rare will be the occasion when a Board is held to have gone wrong in refusing it on a rule 51 charge-or its equivalent rule 33 in Northern Ireland. Since Boards adjudicate only on "especially grave" and "graver" offences (the latter largely corresponding to "more serious" charges in Northern Ireland), if the fact of a charge appearing in the latter category (as opposed to being one which can only be elevated to "graver offence" status under the governor's rule 51(2) power) is not automatically to entitle a prisoner to representation, then attention will turn to the other Webster criteria. As regards the first of these--whether a difficult point of law was at issue-Webster J's decision in Norley could have the effect of narrowing the scope of this considerably. It suggests that the Board must consider the particular argument or defence each prisoner makes rather than the general nature of the charge or his defence. Such a particularised inquiry would be of limited susceptibility to judicial review. In view of recent decisions finding disciplinary tribunals to have misinterpreted the prison rules, ${ }^{94}$ it is perhaps surprising to find the courts narrowing the occasions on which prisoners can obtain professional assistance in dealing with points of law and hence throwing them back on the advice of the Board. As regards the third point, the rejection of a right to counsel to deal with difficult questions of fact as opposed to law appears to indicate that the issue of the prisoner's ability to defend himself will turn purely on the intelligence of the particular prisoner. ${ }^{95}$ Apart from some disquiet that it may only be by the end of the hearing that the Board will really be able to judge a prisoner's capacity to conduct

93 Quotation from LEXIS transcript.

94 See, eg, King and McConkey supra n 62.

95 This was essentially the approach taken to the issue of the prisoner's competence in $I n$ re Hone and McCartan's application. In refusing representation Lord Lowry LCJ noted the prisoner was "an intelligent and articulate man". 
his own defence, such a view would appear to ignore, or at least underestimate, the structural problems for a prisoner in conducting his own defence that I outlined earlier.

The outcome of these decisions would suggest that the courts' attitude to the question of legal representation in prison hearings is that it should be available in "special" cases where the charge is particularly severe or the prisoner particularly incapable of defending himself. Norley's case was, as Webster J stated, "typical of very many cases in which legal representation is neither necessary nor desirable". ${ }^{96}$ Tarrant, thus, will not be used to develop a general right to representation. Indeed, these decisions sound a warning for those who seek to use the courts to reform the lawlessness of prison life. Rather than introduce a right to representation which, it seems, would be one element of the rule of law in prison life, the courts have suggested that this will be available only at the margins, with the risk that this compromise will legitimate denials of justice elsewhere. ${ }^{97}$ Perhaps this is not surprising. A right to representation and its widespread exercise could necessitate widespread changes in prison administration and resource allocation. Given their lack of detailed knowledge of such matters, the courts may feel this is a task best left to the legislature, despite the fact that the legislature has not shown great interest in the issue thus far. Reform at the margins does not raise such problems. Such reticence, however, may also result from an underestimation of the value of representation. This would appear to have been the case with the decision of Forbes J in $R \mathrm{v}$ Board of Visitors' HM Prison Swansea, ex parte McGrath. ${ }^{98}$ The hearing in this case occurred after the Tarrant decision when the Home Office had changed the information given to prisoners prior to the hearing to include a reference to being able to request legal representation. McGrath's form did not contain this information and at the hearing the Board failed to inform him of his right to request representation. Forbes J agreed that this constituted a breach of rule $7(1)$ of the Prison Rules ${ }^{99}$ but opined that any breach of natural justice was of a "purely procedural and ancillary nature". In particular he concluded that it was certainly not on a par with the prison authorities' failure to inform the prisoner of a valuable witness which had been felt sufficient to justify certiorari in $R \mathrm{v}$ Blunderstone Board of Prison Visitors, ex parte Fox-Taylor. ${ }^{1}$ Given the arguments made in this paper as to how representation can alter the whole character of a

96 Since Tarrant many judicial review decisions have upheld refusals to grant legal representation. See, eg, Norley; $R$ v Pentonville Prison Board of Visitors, ex parte Rutherford, The Times, 21 February 1985; $R$ v Leicester Prison Board of Visitors, ex parte Fraser Unreported, 10 December 1984; $R$ v Parkhurst Prison Board of Visitors, ex parte Crowley Unreported, 3 December 1984; In re Lillis's Application (1984) 15 NIJB; In re Daly's Application Unreported 1984.

97 For a discussion of the way "progressive" legal doctrine can legitimate the status quo it seeks to change see Freeman, "Legitimizing Racial Discrimination through Antidiscrimination Law. A Critical Review of Supreme Court Doctrine" (1978) 62 Minnesota LR 1049.

98 The Times, 21 November 1984.

99 Rule 16(1) in Northern Ireland.

1 [1982] 1 All ER 646. 
hearing, it is difficult to see how failing to make a prisoner aware of its availability could be seen as a purely technical breach. Perhaps even more remarkably Forbes J appeared to come to this view before concluding that McGrath would not in any case have been entitled to representation.

\section{THE PRIOR COMMITTEE AND REPRESENTATION}

The Prior Committee carried out an extensive review and made detailed recommendations in relation to most aspects of prison discipline. ${ }^{2}$ Most of these are beyond the scope of this paper and perhaps the most significant, that Boards of Visitors cease to hear charges and be replaced by an independent Prison Disciplinary Tribunal with a legally qualified chairman, has already been rejected by the Government who recommended instead the continuation of lay adjudication, probably by splitting Boards of Visitors into adjudicators and investigators. ${ }^{3}$

The Committee ultimately came down against granting a right to representation before the proposed new Tribunals but recommended that there continue to be a discretion to be exercised on the Webster criteria. Although the Home Office in its reply to Prior has accepted this in respect of its own version of the Tribunals without comment, the decision was not reached easily in the Committee itself. In testament to the disagreements the report sets out both the arguments for and against a right to legal representation. ${ }^{4}$ In keeping with the trend I identified at the outset of this paper for arguments of law and policy to be closely related in this area, the arguments for tended to resemble closely those discussed in the natural justice section and hence I do not intend to spend too much time on them here.

The arguments against a right to legal representation, which ultimately prevailed in the Prior Committee, were composed of both principle and pragmatism. The arguments of principle mainly stressed the dangers of making these hearings too "adversarial" and the fact that courts have concluded that fairness in this area does not necessitate the protections of the criminal trial. As I have argued earlier, these hearings already are "adversarial" and the courts have not adequately resolved what fairness does require. The arguments of pragmatism stressed delay and costs in both direct and indirect aspects. These I hope I have shown are not entirely clear when weighed against the advantages in reducing tension resulting from perceived arbitrariness in prison life. Admittedly, Prior had more evidence on which to base these cost equations than might be available to most courts but even this is not without question. For example, the Committee's conclusion that present delays were

2 Although the Committee's report was confined to prisons in England and Wales any proposed reforms in Northern Ireland would no doubt be influenced by its analysis.

3 See The Prison Disciplinary System in England and Wales op cit supra n 72, para 34.

4 Prior Report, op cit supra n 8, vol 1, paras 10.9-10.23. 
unacceptable (averaging 86 days between the grant of representation and the hearing) was based purely on a survey of applications for representation made between the Tarrant case in November 1983 and June 1985. As the Committee notes, the Tarrant decision caught both the prison service and local solicitors (few of whom knew anything about prison disciplinary hearings) unprepared. As the prison authorities become more used to making provision for cases involving legal representation and more lawyers become involved in the area, thus reducing the dependence on the few firms which specialise in it, one wonders if these delays might not be reduced.

In coming to its conclusion the arguments from pragmatism proved most significant for, as the report states, while some committee members felt there should be no right to representation in principle, others concluded that it would be wrong in principle to leave the issue of representation to the discretion of the Tribunal; they concluded that "there could be substantial practical difficulties in conceding an unfettered right to representation". 5 This theme of practical difficulties is echoed by the Home Office, whose rejection of the Prior proposals for an Independent Tribunal with a legally qualified chairman was based

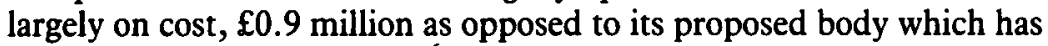
annual costs of $£ 0.4$ million. ${ }^{6}$

Ultimately one's main criticism of the Prior proposals in this area is that they would appear to sacrifice principle to expediency and to reach a conclusion which represents, not a compromise between the claims of natural justice and efficient administration, but a clear preference for the latter. In their own words, the right to legal representation is to be denied, not on its own merits but because of a risk that its widespread abuse might cause major administrative problems for the prison system. ${ }^{7}$ In so concluding they may merely be reflecting their own terms of reference. The Committee were to make their investigations and recommendations against an accepted background of a rising prison population, already overcrowded prisons, and little likelihood of any substantial changes occurring in this situation. In these circumstances recommending a clear enforcement of prisoners' rights without being able to suggest the administrative and policy changes that could make this a reality might seem a pointless exercise. In making these criticisms I am not arguing that delay in hearing charges is unimportant; there is a very real sense in which justice delayed is justice denied. My argument is merely that if it is agreed that prisoners should in principle have a right to representation, should not efforts be devoted to examining ways in which the management of the prison can be altered and resources allocated to facilitate that right, rather than abandoning it because, in the present context, it is difficult to achieve.

5 Prior Report, op cit supra n 8, para 10.19.

6 See The Prison Disciplinary System in England and Wales op cit supra $\mathrm{n} 72$, para 34.

7 Prior Report, op cit supra n 8, vol 1, para 10.21. 
If the Committee was hoping overall to produce a document acceptable to the Government in practical terms, its objective failed. The Home Office initially expressed support for the Prior Committee proposals, apparently seeing them as the best alternative to what they feared after Tarrant would be a system dominated by lawyers. However, as Boards exercising their discretion began to refuse representation and the courts upheld their decisions, these fears came to seem groundless. ${ }^{8}$ Hence, encouraged by the view that the existing arrangements would allow only a fairly minor role for legal representatives, they decided to reject several parts of the report. Two of these rejections may strengthen the case for a right to legal representation. First, the Government will not ensure that a magistrate's clerk will always be available to assist the new lay tribunal on matters of law, nor that any of its members will be legally qualified. The lack of legal expertise in the tribunal has always been seen as a reason for having legal representation for the defendant. ${ }^{9}$ Secondly, unlike Prior, the Government proposes that there will be no appeal from the decisions of the new tribunal which will still have power to order up to 120 days' loss of remission on any one charge. The lack of opportunity to review the substance of Board hearings has already been one reason for the search for more stringent procedural protections. By rejecting Prior's proposals on the former, the Government may invite more litigation on the latter.

\section{CONCLUSION}

The conclusion of this paper is relatively simple. I hope I have shown, first, that natural justice does in some circumstances require that to be heard a person has a right to be heard by a lawyer. Secondly, that there are strong arguments that prison disciplinary hearings are one of those circumstances. Thirdly, that neither precedent nor policy provides convincing arguments against recognising that right. This right could be founded in domestic or European law, though the preference in this paper is for domestic law. Undoubtedly implementation of the policy espoused in this paper carries with its risks: risks that the fears of the Prior Committee might come to pass, risks that an absolute right to legal representation would lead to an increase in delays and tension in the prison, risks that the prison authorities might respond to this increasing legalisation of disciplinary proceedings by ensuring that charges are brought before governors rather than Boards and, in England and Wales at least, by increasing the use of transfer and rule 43 segregation ${ }^{10}$ to deal with what are seen as troublesome prisoners. These strategies, currently at least, would be less subject to legal scrutiny. ${ }^{11}$ Time alone will tell on

8 See The Guardian, 2 June 1986.

9 See Fitzgerald, op cit supra n 41, p 36.

10 Rule 25 in Northern Ireland.

11 In England and Wales as a result of King supra n 46 governors' hearings are not susceptible of judicial review. The position is otherwise in Northern Ireland as a result of In re McKiernan's application (1986) NIJB 6. For decisions concluding that courts have limited powers over other aspects of prison life see Williams v Home Office (No 2) 
these matters but it is perhaps significant that prisoners, no doubt aware of these risks, have continued to push for a right to legal representation. Moreover, the realisation that control through disciplinary powers will be subject to the outside scrutiny of lawyers representing prisoners might assist elements within prison administration to devise and argue for more constructive ways of maintaining order within the prison. ${ }^{12}$

So much for the desirability of establishing a right to legal representation. A more pressing question, perhaps, is whether it will come to pass. The courts, while not providing a convincing argument against recognising such a right, have hardly shown much sympathy for it. The House of Lords, however, has yet to consider the issue, though it is soon to have the opportunity to do so. ${ }^{13}$ In the only major prisoners' case to reach the House previously ${ }^{14}$ their lordships gave what has often been seen by prisoners' rights advocates as the most progressive decision ever delivered by a British court on the issue. ${ }^{15}$ Whether their lordships could be persuaded to give a similar declaration of principle on a matter with more far reaching consequences for prison administration is open to question.

Parliament is more likely to get an opportunity to discuss the question as the Government is pledged to put its alternatives to the Prior proposals in a Criminal Justice Bill for 1986/7. Prisons have rarely been high on the political agenda and most MPs' interest in what happens to people in prison (as opposed to who should be sent there) is sporadic. While press coverage of recent prison riots, legal actions and the Prior proposals may have raised that interest somewhat, it must be doubtful whether a consensus can be established to differ from whatever the Government proposes.

Thus in the short term the legal representation issue may continue to centre around how courts and Boards of Visitors interpret the Webster criteria. There is evidence to show that Boards have not confined

[1981] 1 All ER 1211; McKernan v Governor HM Prison Belfast [1983] NI 83 (removal from association); $R$ v Secretary of State for Home Department, ex parte McAvoy [1984] 3 All ER 417 (transfer); and generally Richardson, $\mathcal{F}$ udicial Intervention in Prison Life in Accountability and Prisons, op cit supra n 29, pp 46-60. The Prior Committee did not notice any marked increase in the use of rule 43 segregation since legal representation was granted in the Tarrant decision, op cit supra n 8, vol 1, para 2.37.

12 See, eg, Jacobs' view that court decisions ruling aspects of prison administration or conditions unlawful in the United States assisted some prison officials to push through reforms that would otherwise have been blocked within the administration: The Prisoners Rights Movement and its impacts 1960-80 in Crime and fustice: An Annual Review of Research (Norval and Morris eds), vol 2, pp 429-70 (1980).

13 The House of Lords granted leave to hear this question in the McCartan case. See The Belfast Telegraph 11 February 1987.

14 Raymond v Honey [1982] I All ER 756.

15 See especially Lord Wilberforce's oft quoted remark that "under English law, a convicted prisoner, in spite of his imprisonment, retains all rights which are not taken away expressly or by necessary implication" ibid, p 759 . 
representation to rule 52 charges. ${ }^{16}$ For the pessimistic, however, the signs are there that any change in this attitude would not be checked by the judiciary. Only recognising a right to representation would ensure that the courts' clear declaration in establishing natural justice in prison disciplinary hearings does not degenerate into a matter of symbol rather than substance.

STEPHEN LIVINGSTONE^

16 Figures produced for the Prior report show that in 1984 Boards of Visitors heard no mutiny and only 5 charges of doing gross personal violence to an officer, yet legal representation was granted in around 80-100 cases in the same period, op cit supra $\mathrm{n} 8$, vol 2 , appendix 10 , tables 1 and 4 . This, however, still amounted to only about $4 \%$ of all cases before Boards and representation was granted in less than $30 \%$ of cases in which prisoners requested it.

- BA, LLM, Lecturer in Law, Queen's University, Belfast. My thanks are due to Brigid Hadfield for her very valuable comments on an earlier version of this article. Remaining errors are my own responsibility. 